\title{
LATITUDINAL ANALYSIS OF RAINFALL INTENSITY AND MEAN ANNUAL PRECIPITATION IN CHILE
}

\author{
Roberto Pizarro $^{1}$, Rodrigo Valdés ${ }^{*}$, Pablo García-Chevesich ${ }^{2}$, Carlos Vallejos ${ }^{1}$, Claudia Sangüesa ${ }^{1}$, \\ Carolina Morales ${ }^{1}$, Francisco Balocchi ${ }^{1}$, Alejandro Abarza ${ }^{1}$, and Roberto Fuentes ${ }^{1}$
}

The study and analysis of precipitation has become a crucial tool in understanding the temporal and spatial behavior of water resources, in terms of availability and impact on extreme events. The objective of this study was to evaluate different rainfall parameters (intensities for 1 - $\mathrm{h}$ duration $\mathrm{D}=1 \mathrm{~h}$ and return periods of $\mathrm{T}=5$ and $100 \mathrm{yr}$, and mean annual precipitation) for different latitudinal and climatic zones in Chile. We analyzed the information recorded on thousands of pluvial bands and rain gauges for 49 stations; this because it is unclear how rainfall intensities change along the country (though total amounts do), in addition to a lack of literature focused on ranges and amounts on the behavior of rainfall variables. The Gumbel probability distribution function (PDF) and mathematical rainfall intensity formulas were used to develop intensity-duration-frequency (IDF) curves for each station. Maximum and minimum rainfall intensity values for T $=100 \mathrm{yr}$ ranged from 8.79 (hyperarid zone) to $40.17 \mathrm{~mm} \mathrm{~h}^{-1}$ (subhumid-humid zone). Total annual rainfall values ranged between 43.9 (hyperarid zone) and $3891.0 \mathrm{~mm} \mathrm{yr}^{-1}$ (humid zone). Additionally, the real maximum intensity registered on each station was analyzed, determining its exceedance probability. Likewise, multiple comparisons were made to detect significant differences between the gauge stations and different climatic zones using the Kruskal Wallis test $($ alpha $=0.05)$. Differences between maximum and minimum values registered for all stations were as much as 80 times for total rainfall amounts and 4.5 times for rainfall intensities $(\mathrm{T}=100 \mathrm{yr}$ ). However, maximum rainfall intensities values were similar at different latitudes, suggesting the absence of correlation between maximum rainfall intensity and annual rainfall amount, as the latter variable increased gradually with latitude.

Key words: Precipitation, frequency-duration-intensity curves, IDF curves, rainfall intensity.

$\mathrm{P}$ recipitation is often the principal hydrological contribution for a watershed and usually improves the general conditions of drainage. Nevertheless, extreme precipitation events often cause serious problems worldwide, such as flooding and their consequences for human lives and property (Maidment, 1996).

Hydrologic phenomena, such as precipitation, floods, and droughts, are inherently random by nature. These physical processes are not fully understood due to the complexity of the hydrologic cycle; for instance, reliable deterministic mathematical models have yet to be developed. Statistical approaches have been commonly adopted in order to provide useful analyses for design of hydraulic pathways and structures (Grimaldi et al., 2011). In this context, rainfall can be characterized in terms of its frequency, duration, and intensity, with intensity being most relevant to the less frequent but more damaging high-intensity events. Using statistical techniques these

${ }^{1}$ University of Talca, Facultad de Ciencias Forestales, Casilla 747, Talca, Chile. "Corresponding author (rodrigovaldes@utalca.cl).

${ }^{2}$ University of Arizona, Department of Agricultural and Biosystems Engineering, Shantz Bldg \#38, Room 403, PO Box 210038, Tucson, Arizona, USA.

Received: 4 October 2011

Accepted: 25 May 2012. three variables (intensity, duration, and frequency) can be correlated to create intensity-duration-frequency (IDF) curves, based on maximum precipitation intensities. IDF curves are crucial in the design of storm water management structures (Haan, 2002) and are useful tools for watershed management, such as prediction of water erosion. Such phenomenon has been evaluated using rainfall simulators (Sanguiesa et al., 2010), that generate rainfall with a known intensity and duration on an erosion plot in a controlled manner, thus making it possible to quantify superficial runoff and soil loss and predict erosion with a high level of detail (Martínez-Mena et al., 2001). Artificially generated rainfall in these simulators must be calibrated according to maximum values of rainfall intensity (IDF curves) corresponding to the location of the study site.

Additionally, IDF curves are used to determine design parameters for soil and water conservation practices. According to Pizarro et al. (2005), the design must include at least four basic hydrological parameters: a return period, an IDF curves, a runoff coefficient, and soil infiltration capacity. IDF curves can be represented as mathematical functions used to determine rainfall intensity by inputting frequency values (years) and duration (minutes or hours). Furthermore, IDF curves have been widely used by different authors. Willems 
(2000) separated both convective and frontal storms in terms of their peak-over-threshold intensity distributions in Belgium, helping to better understand what factors affect IDF curves and their scaling properties. Bougadis and Adamowski (2006) used traditional techniques to compare the scaling properties of extreme rainfall IDF curves using data collected in Ontario, Canada. The authors concluded that the scale approaches were more efficient and gave more accurate estimates through comparing observed data. Other authors have focused IDF research on analyzing and developing mathematical functions (Veneziano and Furcolo, 2002; Pereyra-Díaz et al., 2004; Langousis and Veneziano, 2007), the effects of topography and elevation (Dairaku, 2004), and studying ungauged areas of watersheds (Watkins et al., 2005).

IDF curves analyses have been conducted in Vietnam (Minh Nhat et al., 2006), Japan (Minh Nhat et al., 2008), Mexico (Hallack-Alegria and Watkins Jr., 2007), and many other places worldwide. Pizarro et al. (2001) developed IDF curves for the Maule Region in Chile and UNESCO (2007) updated IDF curves for a great portion of the Chilean territory (between Coquimbo and La Araucanía Regions). However, there is no scientific evidence regarding the values and existing differences among the curves developed for the country, including geographical extremes of Chile. Therefore, the objective of this study was to evaluate maximum rainfall intensities $(D=1 \mathrm{~h}$ and $\mathrm{T}=5$ and $100 \mathrm{yr}$ ) and mean annual precipitation for different latitudes and climatic zones of Chile, based on information obtained from pluvial bands and rain gauges from 49 stations distributed along the country, in order to determine if a pattern able to explain the behavior of IDF curves at different latitudes (e.g. under different climates) exists.

\section{MATERIAL AND METHODS}

The study was done using information on rainfall intensity, obtained from 49 gauge stations distributed along the country (Figure 1A), property of Chile's Water General Direction (Dirección General de Aguas), and installed under the norms and specifications of the World Meteorological Organization (WMO). Stations were located under different climates, varying from hyperarid and semiarid zones to humid and cold semiarid (UNESCO, 2006; 2010), all within the 12 Chilean first-order administrative regions (Figure 1B). Chile's geography is unusual, being the country with the world's largest length-to-width ratio $(4300 \mathrm{~km}$ to about $177 \mathrm{~km}$ in average) (IGM, 2008). But most importantly for this study is to notice the wide heterogeneity of the country's climates, a direct consequence of large latitudinal changes (high and low atmospheric pressure zones), combined with important topographic features, like the presence of Los Andes and La Costa mountain ranges, and the cold Humboldt Current in the Pacific Ocean. Moreover, this north-to-south general climatic variability begins with the extreme aridity of desert zones, ends with cold-rainy climates in the extreme south of the country, passing through temperate-warm climates in central Chile (INE, 2007).

For $86 \%$ of the rain gauges IDF curves were obtained using maximum annual precipitation intensities. However, partial time series, as described by Linsley et al. (1977) were used for the remaining stations (14\%) since were recently established and had less than five years' worth of data. A selection criterion of two or three storm events per year was established to increase the number of data available for analysis. It is also not worthless to mention
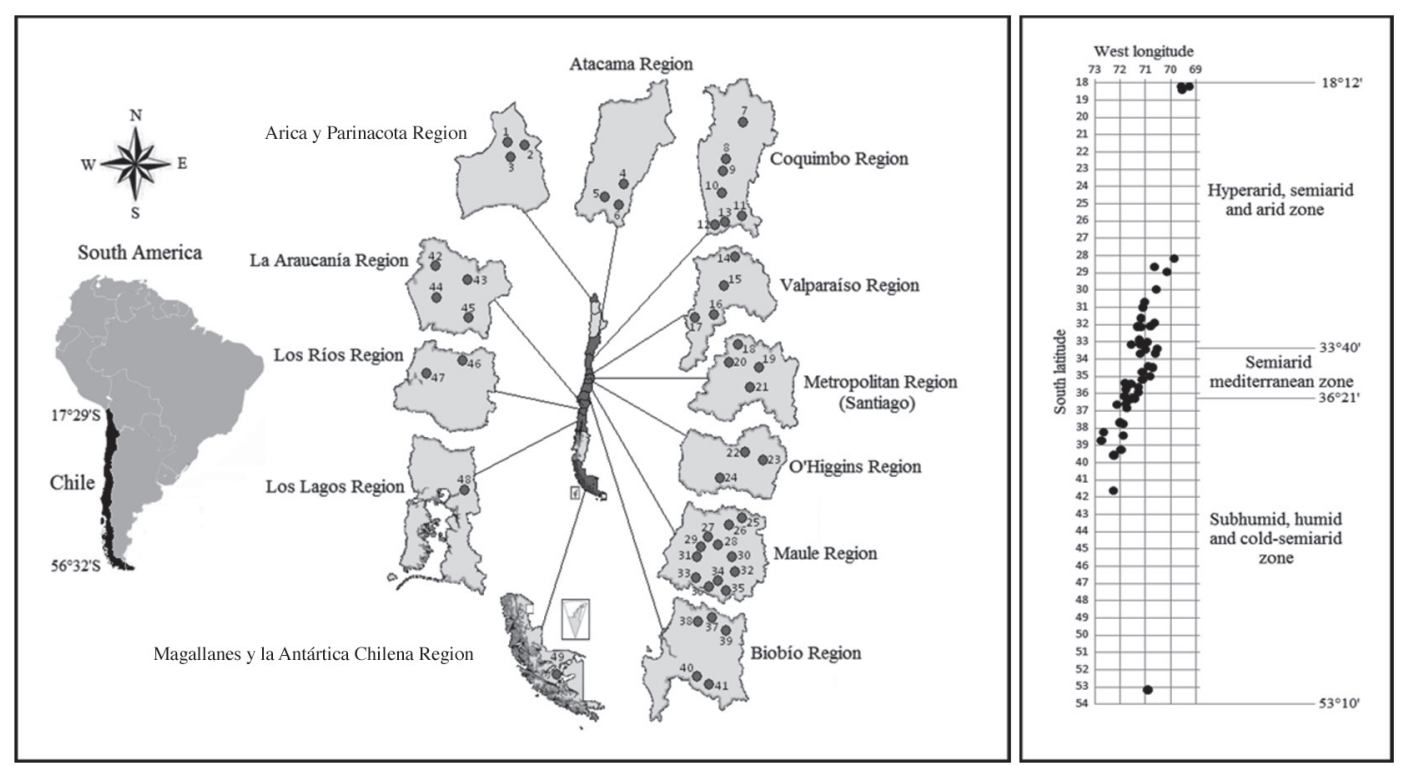

Figure 1. (A) Spatial distribution of the 49 gauge stations on each administrative Region of Chile. (B) Spatial distribution of the 49 gauge stations on each climatic zone of Chile. 
that the historical data documented at the analyzed stations were between 10 and 40 records (47\% with more than 20 records, $39 \%$ between 15 and 19 records, and $14 \%$ between 10 and 14 records).

Table 1 lists general information about the gauge stations (number of years on record, administrative region, geographical coordinates, and climatic zone). The Gumbel procedure (Gumbel, 1958) was applied to each data series listed on Table 1 in order to obtain a probability distribution for return periods of $\mathrm{T}=5$ and 100 yr for each station. The Gumbel probability distribution function (PDF) is expressed as $\mathrm{F}(\mathrm{x})=\mathrm{e}^{-\mathrm{e}^{-\mathrm{d} \cdot(\mathrm{x}-\mathrm{u})}}$, where $x$ is the value of the random variable, $d$ and $u$ are parameters of the function, and $e$ is the Neper constant. Similarly, the probability of occurrence, or the probability for a random variable to have a value equal or lower than a certain number $X$, is given by the probability distribution function defined as $\int_{-\infty} \mathrm{f}(\mathrm{x}) \mathrm{dx}=\mathrm{P}(\mathrm{x} \leq \mathrm{X})=1-(1 / \mathrm{T})$, (where $T$ represents the return period in years). The probability of exceedence, defined as the probability for the random variable to exceed a given value, is determined by the expression $P(x>X)=1-F(x)=1 / T$. On the same way, it is important to add that the Gumbel function has been used in studies related to extreme meteorological events, and has provided a precise fit to daily and annual hydrological values (Mintegui y Robredo, 1993). Similarly, Stol (1971), cited in Dickinson (1977), states that Gumbel is the best approach in representing extreme annual rainfall. Additionally, the Gumbel function has been cited extensively in related literature due to its ability to fit extreme values (e.g. Linsley et al., 1977; Témez, 1978; Pizarro, 1986; Ponce, 1989; Chow et al., 1994; Monsalve, 1999).

Table 1. Climatic zone, administrative Region, location, and years of record for each gauge station.

\begin{tabular}{|c|c|c|c|c|c|c|c|}
\hline Climatic zone & Region & Station/Location & $\begin{array}{c}\text { Map } \\
\text { number }\end{array}$ & S lat & W long & $\begin{array}{l}\text { Registration } \\
\text { period }\end{array}$ & $\begin{array}{l}\text { Range } \\
\text { (n) }\end{array}$ \\
\hline \multirow[t]{6}{*}{ Hyperarid } & \multirow[t]{3}{*}{ Arica y Parinacota } & Putre $(*)$ & 1 & $18^{\circ} 12^{\prime}$ & $69^{\circ} 35^{\prime}$ & 2004-2008 & 15 \\
\hline & & Parinacota $(*)$ & 2 & $18^{\circ} 12^{\prime}$ & $69^{\circ} 16^{\prime}$ & $2004-2007$ & 12 \\
\hline & & Central Chapiquiña $(*)$ & 3 & $18^{\circ} 23^{\prime}$ & $69^{\circ} 33^{\prime}$ & $2005-2008$ & 12 \\
\hline & \multirow[t]{3}{*}{ Atacama } & Iglesia Colorada & 4 & $28^{\circ} 10^{\prime}$ & $69^{\circ} 52^{\prime}$ & $1988-2008$ & 20 \\
\hline & & Santa Juana & 5 & $28^{\circ} 40^{\prime}$ & $70^{\circ} 39^{\prime}$ & $1988-2005$ & 17 \\
\hline & & Albaricoque $(*)$ & 6 & $28^{\circ} 56^{\prime}$ & $70^{\circ} 09^{\prime}$ & $1988-2008$ & 30 \\
\hline \multirow[t]{7}{*}{ Arid-semiarid } & \multirow[t]{7}{*}{ Coquimbo } & Rivadavia & 7 & $29^{\circ} 58^{\prime}$ & $70^{\circ} 34^{\prime}$ & $1976-2001$ & 25 \\
\hline & & Embalse La Paloma & 8 & $30^{\circ} 41^{\prime}$ & $71^{\circ} 02^{\prime}$ & $1962-2002$ & 40 \\
\hline & & Embalse Cogotí & 9 & $31^{\circ} 00^{\prime}$ & $71^{\circ} 06^{\prime}$ & $1966-2002$ & 33 \\
\hline & & Illapel & 10 & $31^{\circ} 38^{\prime}$ & $71^{\circ} 10^{\prime}$ & $1976-2002$ & 27 \\
\hline & & La Tranquilla & 11 & $31^{\circ} 54^{\prime}$ & $70^{\circ} 39^{\prime}$ & $1966-2002$ & 34 \\
\hline & & Los Cóndores & 12 & $32^{\circ} 07^{\prime}$ & $71^{\circ} 19^{\prime}$ & $1978-2002$ & 22 \\
\hline & & Quelón & 13 & $32^{\circ} 09^{\prime}$ & $71^{\circ} 10^{\prime}$ & 1973-2002 & 27 \\
\hline \multirow[t]{8}{*}{ Semiarid } & \multirow[t]{4}{*}{ Valparaíso } & Hacienda Pedernal & 14 & $32^{\circ} 06^{\prime}$ & $70^{\circ} 48^{\prime}$ & $1978-2001$ & 10 \\
\hline & & Quillota & 15 & $32^{\circ} 53^{\prime}$ & $71^{\circ} 15^{\prime}$ & $1979-2002$ & 12 \\
\hline & & Embalse Lliu-Lliu & 16 & $33^{\circ} 08^{\prime}$ & $71^{\circ} 13^{\prime}$ & $1979-2002$ & 14 \\
\hline & & Lago Peñuelas & 17 & $33^{\circ} 09^{\prime}$ & $71^{\circ} 33^{\prime}$ & $1974-2001$ & 21 \\
\hline & \multirow[t]{4}{*}{ Metropolitana } & Embalse Rungue & 18 & $33^{\circ} 01^{\prime}$ & $70^{\circ} 55^{\prime}$ & $1984-2000$ & 16 \\
\hline & & Cerro Calán & 19 & $33^{\circ} 23^{\prime}$ & $70^{\circ} 32^{\prime}$ & $1983-2000$ & 17 \\
\hline & & Los Panguiles & 20 & $33^{\circ} 26^{\prime}$ & $71^{\circ} 00^{\prime}$ & $1985-2000$ & 15 \\
\hline & & Pirque & 21 & $33^{\circ} 40^{\prime}$ & $70^{\circ} 36^{\prime}$ & $1984-2000$ & 17 \\
\hline \multirow[t]{3}{*}{ Semiarid-Mediterranean } & \multirow[t]{3}{*}{ Libertador General Bernardo O'Higgins } & Rengo & 22 & $34^{\circ} 25^{\prime}$ & $70^{\circ} 53^{\prime}$ & $1970-2002$ & 26 \\
\hline & & Central Las Nieves & 23 & $34^{\circ} 29^{\prime}$ & $70^{\circ} 42^{\prime}$ & 1971-2002 & 27 \\
\hline & & Convento Viejo & 24 & $34^{\circ} 46^{\prime}$ & $71^{\circ} 07^{\prime}$ & $1972-2002$ & 21 \\
\hline \multirow[t]{12}{*}{ Mediterranean } & \multirow[t]{12}{*}{ Maule } & Los Queñes & 25 & $35^{\circ} 00^{\prime}$ & $70^{\circ} 49^{\prime}$ & $1988-2002$ & 15 \\
\hline & & Potrero Grande & 26 & $35^{\circ} 12^{\prime}$ & $71^{\circ} 07^{\prime}$ & $1988-2002$ & 15 \\
\hline & & Pencahue & 27 & $35^{\circ} 23^{\prime}$ & $71^{\circ} 48^{\prime}$ & $1982-1998$ & 17 \\
\hline & & Talca & 28 & $35^{\circ} 26^{\prime}$ & $71^{\circ} 35^{\prime}$ & $1982-1998$ & 17 \\
\hline & & San Javier & 29 & $35^{\circ} 36^{\prime}$ & $71^{\circ} 44^{\prime}$ & $1988-2002$ & 15 \\
\hline & & Colorado & 30 & $35^{\circ} 38^{\prime}$ & $71^{\circ} 16^{\prime}$ & 1982-1998 & 14 \\
\hline & & Melozal & 31 & $35^{\circ} 45^{\prime}$ & $71^{\circ} 47^{\prime}$ & $1982-1998$ & 17 \\
\hline & & Embalse Ancoa & 32 & $35^{\circ} 54^{\prime}$ & $71^{\circ} 17^{\prime}$ & $1988-2002$ & 15 \\
\hline & & Parral & 33 & $36^{\circ} 09^{\prime}$ & $71^{\circ} 50^{\prime}$ & $1982-1998$ & 17 \\
\hline & & Embalse Digua & 34 & $36^{\circ} 15^{\prime}$ & $71^{\circ} 32^{\prime}$ & $1988-2002$ & 15 \\
\hline & & Embalse Bullileo & 35 & $36^{\circ} 17^{\prime}$ & $71^{\circ} 26^{\prime}$ & $1982-1998$ & 16 \\
\hline & & San Manuel $(*)$ & 36 & $36^{\circ} 21^{\prime}$ & $71^{\circ} 39^{\prime}$ & $1996-2002$ & 14 \\
\hline \multirow[t]{5}{*}{ Subhumid humid } & \multirow[t]{5}{*}{ Biobío } & Embalse Coihueco & 37 & $36^{\circ} 35^{\prime}$ & $71^{\circ} 47^{\prime}$ & $1984-2003$ & 20 \\
\hline & & Chillán Viejo & 38 & $36^{\circ} 38^{\prime}$ & $72^{\circ} 08^{\prime}$ & $1974-2003$ & 29 \\
\hline & & Embalse Diguillín & 39 & $36^{\circ} 50^{\prime}$ & $71^{\circ} 44^{\prime}$ & $1965-2003$ & 38 \\
\hline & & Quilaco & 40 & $37^{\circ} 41^{\prime}$ & $72^{\circ} 00^{\prime}$ & $1965-2003$ & 39 \\
\hline & & Cerro El Padre & 41 & $37^{\circ} 46^{\prime}$ & $71^{\circ} 53^{\prime}$ & $1976-2003$ & 28 \\
\hline \multirow[t]{7}{*}{ Humid } & \multirow[t]{4}{*}{ La Araucanía } & Traiguén & 42 & $38^{\circ} 15^{\prime}$ & $72^{\circ} 40^{\prime}$ & $1988-2003$ & 16 \\
\hline & & Curacautín & 43 & $38^{\circ} 26^{\prime}$ & $71^{\circ} 53^{\prime}$ & 1991-2003 & 13 \\
\hline & & Pueblo Nuevo & 44 & $38^{\circ} 44^{\prime}$ & $72^{\circ} 45^{\prime}$ & $1989-2003$ & 15 \\
\hline & & Pucón & 45 & $39^{\circ} 16^{\prime}$ & $71^{\circ} 58^{\prime}$ & $1984-2003$ & 20 \\
\hline & \multirow[t]{2}{*}{ Los Ríos } & Lago Calafquén $(*)$ & 46 & $39^{\circ} 34^{\prime}$ & $72^{\circ} 15^{\prime}$ & 1997-2008 & 24 \\
\hline & & Llancahue & 47 & $39^{\circ} 50^{\prime}$ & $73^{\circ} 10^{\prime}$ & $1977-2007$ & 31 \\
\hline & Los Lagos & Puelo $(*)$ & 48 & $41^{\circ} 38^{\prime}$ & $72^{\circ} 16^{\prime}$ & $1997-2008$ & 24 \\
\hline Cold-semiarid & Magallanes y la Antártica Chilena & Punta Arenas & 49 & $53^{\circ} 10^{\prime}$ & $70^{\circ} 54^{\prime}$ & $1983-2008$ & 26 \\
\hline
\end{tabular}

(*) Stations in which two or three annual data were considered. 
In Chile, the Gumbel function was used by Pizarro et al. (2008) to characterize annual precipitation in central Chile. It is also important to add that national experience on recent studies in process of publication demonstrate that the Gumbel function more accurately fits to extreme precipitation and runoff values than other functions, such as Log-Normal or Goodrich and Pearson Type III. However, these latter functions fit more accurately for data in arid and semiarid climates (mostly between south $29^{\circ}$ and $32^{\circ}$ latitude), where data is more variable. However, Linsley et al. (1977) mentioned that although effort has been focused on better defining hydrological data, research suggests that there isn't a unanimously superior distribution. Thus we continued the use of the Gumbel function and validated the results with the Kolomogorov-Smirnov (K-S) Goodness of Fit Test (Massey, 1951), a non-parametric test used on continuous distribution functions $\mathrm{F}(\mathrm{x})$, which is based on comparing the absolute value of the maximum difference between the cumulative distribution functions (observed) in the sorted sample $\mathrm{Fo}(\mathrm{x})$ and the distribution proposed under the null hypothesis $\mathrm{F}(\mathrm{x})$. If the comparison has a sufficiently significant difference between the sample and the proposed distribution function, then the null hypothesis (i.e. the distribution is $\mathrm{F}(\mathrm{x})$ ) is rejected. One hundred percent of the results applied to intensity data were accepted with this test. The coefficient of determination $\left(\mathrm{R}^{2}\right)$ was used to explain the percentage of variation for the dependent variable of the model (Dougherty et al., 2000). In this context, most of the obtained $R^{2}$ values were over 0.8 . In other words, $100 \%$ of the results were considered acceptable by this test, with an average value of 0.9 , supporting the superiority of the Gumbel function for modeling extreme climatic data.

Once the fit was made, the relationships between intensity $\left(\mathrm{mm} \mathrm{h}^{-1}\right)$, duration $(1,2,4,6,12$, and $24 \mathrm{~h})$, and frequency $(5,10,20,30,40,50,60,75$, and $100 \mathrm{yr})$ were determined. Finally, a family of nine negative exponential curves (IDF curves) was built for each gauge station, though only a portion of them was considered for use in this study, as is explained later.

IDF curves are often expressed as a function, to minimize errors and avoid graphical reading (Chow et al., 1994). Hence, a mathematical equation was developed for each family curve. These equations are based on the model proposed by Bernard (1932): $I=\left(k * T^{m}\right) * D^{-n}$, where $I$ is the maximum rainfall intensity $\left(\mathrm{mm} \mathrm{h}^{-1}\right), T$ is the return period (yr), and $D$ is the duration of the storm (h). Also, $k, m$, and $n$ are the regression's parameters.

Once the IDF curves and their respective functions were done for each of the 49 stations, we decided to analyze rainfall intensities for a duration $\mathrm{D}=1 \mathrm{~h}$ (because is the minimum time that human eye can obtain from weekly pluvial bands, being these, the most commonly bands used in Chile), considering return periods of $\mathrm{T}=5$ and 100 yr. In this context is important to mention that extreme events that generate larger impact are generally associated with short durations, even less than $1 \mathrm{~h}$. Similarly, $\mathrm{T}=$ 5 and $100 \mathrm{yr}$ were selected to analyze the two extreme frequencies associated to all the frequencies defined from IDF curves. Additionally, the real maximum intensity registered on each station was analyzed, determining its exceedance probability. Likewise, multiple comparisons were made to detect significant differences between the gauge stations and different climatic zones using the Kruskal Wallis test (alpha $=0.05$ ), a non-parametric statistical test that determines whether samples derive from the same population. This test evaluates the null hypothesis that the means are statistically similar, and is an extension of the Mann-Whitney $U$ test for three or more groups (in this case 49) (Kruskal and Wallis, 1952).

A latitudinal analysis of rainfall intensities $(D=1 \mathrm{~h}, T$ $=5$ and $100 \mathrm{yr}$ ) was performed, with the results expressed graphically. The latitudinal distribution of mean annual precipitation was also considered to find possible correlation and trends.

\section{RESULTS AND DISCUSSION}

Chile has great climatic diversity, which is explained by its wide latitudinal extension and the presence of four well-defined geographic areas: the Andes mountain range to the east, the La Costa mountain range to the west, the intermountain valley, and littoral floodplains. The location of the country next to the Pacific Ocean, the effects of the Humboldt Current, in addition to the Pacific high-pressure zone, give rise to a wide variety of climates, varying from extreme aridity in the north (Arica y Parinacota, and Atacama Regions), to Mediterranean climates (warm temperate) in the center (Libertador General Bernardo O’Higgins and Maule Regions), and cold rainy climates in the extreme south (Aysén del General Carlos Ibáñez del Campo and Magallanes y la Antártica Chilena Regions) (Errázuriz et al., 1998; INE, 2007).

In terms of the length of the analyzed data series, results presented by Ott (1971) show that with the use of $20 \mathrm{yr}$ of data there is $80 \%$ probability of overestimating the design runoff, and $45 \%$ probability that the overestimated values exceeding real values in more than $30 \%$. Linsley et al. (1977) for example recommends avoiding the use of data series shorter than $20 \mathrm{yr}$. However, the same authors state that if necessary, peak flows can be estimated using 2 or $3 \mathrm{yr}$ of observed data. On the other hand, maximum rainfall intensities documented in Chile do not necessarily correlate to higher rainfall amounts during wet periods. In fact, many high intensity values were recorded during dry periods. Besides, the behavior of rainfall intensities in arid climates responds similarly to those in Mediterranean and humid environments (UNESCO, 2007). From a regional perspective and considering the intensity results given by IDF curves, we can assume that there are differences in the quality of the generated 
information, as a consequence of the differences in data series. However, such differences are not as significant as the behavior of rainfall intensities within the national territory. If such differences are represented by minimum extreme values, values associated with return periods of 50 or 100 yr would overestimate the maximum recorded intensity in the data series, meaning that there will always be higher values that securely allowed the development of hydrological design. Therefore, the selection of a series to be analyzed and the return periods to be considered will depend on the project's objective, as well as the respective infrastructure costs. Finally, we should mention that when hydrological data are not abundant and historical data series are insufficient for analysis, it is appropriate to develop a Regional Frequency Analysis (RFA), which is designed to solve this type of problem (Linsley et al. 1977) and has been used to estimate and map the frequency of droughts in northern Chile. The use of RFA implies the availability of information from stations located in areas with similar rainfall regimes (Paulhus and Miller, 1957), generally separated by distances no larger than $160 \mathrm{~km}$ (Ott, 1971).

In this vein, IDF curves were successfully developed for each of the 49 stations, for durations of $1,2,4,6,12$, and $24 \mathrm{~h}$ and return periods of 5, 10, 20, 30, 40, 50, 60, 75 , and $100 \mathrm{yr}$. As previously mentioned only $\mathrm{D}=1 \mathrm{~h}$ and $\mathrm{T}=5$ and $100 \mathrm{yr}$ were considered (Table 2). The lowest rainfall intensities for $1 \mathrm{~h}$ were recorded at Albaricoque station (arid climate) for the two studied return periods. The highest extremes occurred at Lago Peñuelas station (semiarid climate) for $\mathrm{T}=5 \mathrm{yr}$ and Embalse Coihueco (subhumid climate) for $\mathrm{T}=100 \mathrm{yr}$. Higher values were in

Table 2. Maximum rainfall intensity ( $T=5$ and $100 \mathrm{yr}$ ) estimated at each gauge station.

\begin{tabular}{|c|c|c|c|c|c|c|}
\hline \multirow[b]{2}{*}{ Climatic zone } & \multirow[b]{2}{*}{ Station/Location } & \multirow[b]{2}{*}{$\underset{\text { number }}{\text { Map }}$} & \multirow[b]{2}{*}{$\begin{array}{c}\text { Annual rainfall } \\
\text { amount }\end{array}$} & \multirow[b]{2}{*}{$\begin{array}{l}\text { Maximum rainfall } \\
\text { intensity }\end{array}$} & \multicolumn{2}{|c|}{ Intensity of rainfall $1 \mathrm{~h}$} \\
\hline & & & & & $\mathrm{T}=5$ & $\mathrm{~T}=100$ \\
\hline & & & $\mathrm{mm}$ & $\mathrm{mm} \mathrm{h}^{-1}$ & 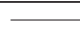 & 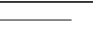 \\
\hline \multirow[t]{6}{*}{ Hyperarid } & Putre & 1 & 237.7 & 7.9 & 5.75 & 10.29 \\
\hline & Parinacota & 2 & 394.0 & 8.5 & 7.05 & 10.72 \\
\hline & Central Chapiquiña & 3 & 195.5 & 8.5 & 6.45 & 11.04 \\
\hline & Iglesia Colorada & 4 & 58.4 & 7.4 & 5.73 & 9.98 \\
\hline & Santa Juana & 5 & 43.9 & 15.5 & 8.90 & 19.62 \\
\hline & Albaricoque & 6 & 84.9 & 6.6 & 4.91 & 8.79 \\
\hline \multirow[t]{7}{*}{ Arid-semiarid } & Rivadavia & 7 & 100.1 & 13.3 & 7.97 & 15.38 \\
\hline & Embalse La Paloma & 8 & 135.4 & 20.0 & 19.00 & 27.49 \\
\hline & Embalse Cogotí & 9 & 168.0 & 20.6 & 10.82 & 20.40 \\
\hline & Illapel & 10 & 179.6 & 16.6 & 9.76 & 18.36 \\
\hline & La Tranquilla & 11 & 251.0 & 15.0 & 9.34 & 17.09 \\
\hline & Los Cóndores & 12 & 241.4 & 15.0 & 10.07 & 18.48 \\
\hline & Quelón & 13 & 300.1 & 15.6 & 9.67 & 16.79 \\
\hline \multirow[t]{8}{*}{ Semiarid } & Hacienda Pedernal & 14 & 247.5 & 17.8 & 12.62 & 20.22 \\
\hline & Quillota & 15 & 361.7 & 18.6 & 13.10 & 22.57 \\
\hline & Embalse Lliu-Lliu & 16 & 571.2 & 23.4 & 19.95 & 31.77 \\
\hline & Lago Peñuelas & 17 & 735.6 & 30.3 & 22.22 & 37.41 \\
\hline & Embalse Rungue & 18 & 372.5 & 17.0 & 11.63 & 18.83 \\
\hline & Cerro Calán & 19 & 441.5 & 19.2 & 13.58 & 21.53 \\
\hline & Los Panguiles & 20 & 361.5 & 14.8 & 11.04 & 19.20 \\
\hline & Pirque & 21 & 470.1 & 15.2 & 11.53 & 18.42 \\
\hline \multirow[t]{3}{*}{ Semiarid-Mediterranean } & Rengo & 22 & 563.8 & 21.5 & 13.68 & 21.43 \\
\hline & Central Las Nieves & 23 & 828.9 & 16.2 & 13.68 & 19.37 \\
\hline & Convento Viejo & 24 & 721.2 & 19.3 & 15.04 & 23.53 \\
\hline \multirow[t]{12}{*}{ Mediterranean } & Los Queñes & 25 & 1183.8 & 25.2 & 18.89 & 30.13 \\
\hline & Potrero Grande & 26 & 1103.1 & 25.7 & 19.14 & 30.66 \\
\hline & Pencahue & 27 & 673.0 & 15.9 & 12.37 & 19.56 \\
\hline & Talca & 28 & 661.9 & 14.3 & 10.78 & 16.27 \\
\hline & San Javier & 29 & 767.5 & 14.2 & 12.14 & 18.04 \\
\hline & Colorado & 30 & 1387.4 & 25.6 & 17.15 & 28.23 \\
\hline & Melozal & 31 & 743.3 & 23.0 & 13.05 & 22.68 \\
\hline & Embalse Ancoa & 32 & 1506.4 & 23.4 & 12.23 & 23.39 \\
\hline & Parral & 33 & 968.8 & 19.3 & 14.77 & 23.68 \\
\hline & Embalse Digua & 34 & 1519.8 & 25.8 & 20.06 & 30.91 \\
\hline & Embalse Bullileo & 35 & 2157.1 & 22.4 & 18.54 & 25.60 \\
\hline & San Manuel & 36 & 1391.7 & 23.0 & 17.62 & 28.49 \\
\hline \multirow[t]{5}{*}{ Subhumid humid } & Embalse Coihueco & 37 & 1512.8 & 36.5 & 21.93 & 40.17 \\
\hline & Chillán Viejo & 38 & 1093.4 & 22.1 & 18.33 & 29.02 \\
\hline & Embalse Diguillín & 39 & 2143.5 & 30.2 & 20.28 & 32.20 \\
\hline & Quilaco & 40 & 1572.1 & 26.0 & 17.62 & 27.62 \\
\hline & Cerro El Padre & 41 & 2131.3 & 28.8 & 19.83 & 30.52 \\
\hline \multirow[t]{7}{*}{ Humid } & Traiguén & 42 & 1016.2 & 20.4 & 13.87 & 22.03 \\
\hline & Curacautín & 43 & 1750.8 & 15.3 & 13.98 & 20.44 \\
\hline & Pueblo Nuevo & 44 & 1201.5 & 14.3 & 13.09 & 18.62 \\
\hline & Pucón & 45 & 2154.5 & 18.9 & 14.18 & 21.39 \\
\hline & Lago Calafquén & 46 & 2113.7 & 17.8 & 14.13 & 19.39 \\
\hline & Llancahue & 47 & 1983.1 & 26.4 & 17.39 & 27.05 \\
\hline & Puelo & 48 & 3891.0 & 16.1 & 12.74 & 20.21 \\
\hline Cold-semiarid & Punta Arenas & 49 & 422.8 & 13.0 & 7.59 & 12.85 \\
\hline
\end{tabular}


general found in Mediterranean and subhumid climates. The highest values on mean annual precipitation were obtained in south-central Chile (humid and mediterranean climates), whereas the lowest amount of rainfall fell, not surprisingly, over stations located in hyperarid climates.

On the other hand, when verifying the relationship between rainfall intensity and elevation, there was no clear trend because similar rainfall intensity values at different elevations (between 0 and $1200 \mathrm{~m}$ a.s.1.) were found. Similarly, for some stations, such as Putre, Central Chapiquiña, or Iglesia Colorada, (among others), located in the northern portion of the country (hyperarid climate) have altitudes that surpass $1200 \mathrm{ma.s.1}$., and have maximum intensities similar to Punta Arenas and other stations located a few meters above sea level, in south extreme of Chile.
A relationship between real maximum rainfall intensities, their corresponding return periods, and their probability of exceeding the maximum-recorded value was made for each station, using the obtained mathematical equations. This analysis allowed the estimation of the probability of surpassing the registered real maximum intensity for each data series, as well as its corresponding return period (Table 3 ). There was a $15 \%$ probability to surpass $23.4 \mathrm{~mm} \mathrm{~h}^{-1}$, the recorded maximum rainfall intensity at Embalse Lliu-Lliu station (semiarid climate), corresponding to a return period of $7 \mathrm{yr}$, the lowest registered return period. This large exceedance probability suggests that high rainfall intensities at that location are common. In contrast, a maximum of $23.4 \mathrm{~mm} \mathrm{~h}^{-1}$ was recorded at Embalse Ancoa station (Mediterranean climate). Nevertheless, the probability of

Table 3. Return periods and exceedence probabilities for maximum rainfall intensities recorded on $1 \mathrm{~h}$ an each gauge station.

\begin{tabular}{|c|c|c|c|c|c|c|}
\hline Climatic zone & Station/Location & $\begin{array}{c}\text { Map } \\
\text { number }\end{array}$ & $\begin{array}{l}\text { Maximum intensity } \\
\text { of rainfall }\end{array}$ & $\begin{array}{c}\text { Year of } \\
\text { occurrence }\end{array}$ & $\begin{array}{l}\text { Return } \\
\text { period }\end{array}$ & $\begin{array}{l}\text { Exceedance } \\
\text { probability }\end{array}$ \\
\hline & & & $\mathrm{mm} \mathrm{h}^{-1}$ & & $\mathrm{yr}$ & $\%$ \\
\hline \multirow[t]{6}{*}{ Hyperarid } & Putre & 1 & 7.9 & 2007 & 21 & 4.9 \\
\hline & Parinacota & 2 & 8.5 & 2005 & 11 & 9.0 \\
\hline & Central Chapiquiña & 3 & 8.5 & 2007 & 36 & 2.8 \\
\hline & Iglesia Colorada & 4 & 7.4 & 1989 & 9 & 10.8 \\
\hline & Santa Juana & 5 & 15.5 & 1997 & 24 & 4.1 \\
\hline & Albaricoque & 6 & 6.6 & 1992 & 15 & 6.5 \\
\hline \multirow[t]{7}{*}{ Arid-semiarid } & Rivadavia & 7 & 13.3 & 2000 & 28 & 3.6 \\
\hline & Embalse La Paloma & 8 & 20.0 & 1997 & 33 & 3.0 \\
\hline & Embalse Cogotí & 9 & 20.6 & 1992 & 53 & 1.9 \\
\hline & Illapel & 10 & 16.6 & 1994 & 30 & 3.4 \\
\hline & La Tranquilla & 11 & 15.0 & 1997 & 47 & 2.1 \\
\hline & Los Cóndores & 12 & 15.0 & 1984 & 29 & 3.5 \\
\hline & Quelón & 13 & 15.6 & 1974 & 34 & 2.9 \\
\hline \multirow[t]{8}{*}{ Semiarid } & Hacienda Pedernal & 14 & 17.8 & 1983 & 32 & 3.1 \\
\hline & Quillota & 15 & 18.6 & 2000 & 19 & 5.2 \\
\hline & Embalse Lliu-Lliu & 16 & 23.4 & 1984 & 7 & 15.0 \\
\hline & Lago Peñuelas & 17 & 30.3 & 1981 & 11 & 8.8 \\
\hline & Embalse Rungue & 18 & 17.0 & 1990 & 48 & 2.1 \\
\hline & Cerro Calán & 19 & 19.2 & 1986 & 19 & 5.3 \\
\hline & Los Panguiles & 20 & 14.8 & 2000 & 15 & 6.6 \\
\hline & Pirque & 21 & 15.2 & 1996 & 40 & 2.5 \\
\hline \multirow[t]{3}{*}{ Semiarid-Mediterranean } & Rengo & 22 & 21.5 & 2001 & 99 & 1.0 \\
\hline & Central Las Nieves & 23 & 16.2 & 1981 & 16 & 6.2 \\
\hline & Convento Viejo & 24 & 19.3 & 2000 & 33 & 3.1 \\
\hline \multirow[t]{12}{*}{ Mediterranean } & Los Queñes & 25 & 25.2 & 2000 & 46 & 2.2 \\
\hline & Potrero Grande & 26 & 25.7 & 2000 & 23 & 4.3 \\
\hline & Pencahue & 27 & 15.9 & 1986 & 26 & 3.8 \\
\hline & Talca & 28 & 14.3 & 1987 & 29 & 3.4 \\
\hline & San Javier & 29 & 14.2 & 1999 & N/A & N/A \\
\hline & Colorado & 30 & 25.6 & 1993 & 84 & 1.2 \\
\hline & Melozal & 31 & 23.0 & 1992 & 48 & 2.1 \\
\hline & Embalse Ancoa & 32 & 23.4 & 2002 & 36 & 2.8 \\
\hline & Parral & 33 & 19.3 & 1993 & 26 & 3.9 \\
\hline & Embalse Digua & 34 & 25.8 & 1992 & 27 & 3.7 \\
\hline & Embalse Bullileo & 35 & 22.4 & 1995 & 31 & 3.2 \\
\hline & San Manuel & 36 & 23.0 & 1998 & 46 & 2.2 \\
\hline \multirow[t]{5}{*}{ Subhumid humid } & Embalse Coihueco & 37 & 36.5 & 2000 & 57 & 1.7 \\
\hline & Chillán Viejo & 38 & 22.1 & 2002 & 19 & 5.2 \\
\hline & Embalse Diguillín & 39 & 30.2 & 1974 & 46 & 2.2 \\
\hline & Quilaco & 40 & 26.0 & 1970 & 54 & 1.9 \\
\hline & Cerro El Padre & 41 & 28.8 & 1980 & 71 & 1.4 \\
\hline \multirow[t]{7}{*}{ Humid } & Traiguén & 42 & 20.4 & 2003 & 54 & 1.9 \\
\hline & Curacautín & 43 & 15.3 & 1994 & 10 & 10.4 \\
\hline & Pueblo Nuevo & 44 & 14.3 & 1992 & 9 & 11.2 \\
\hline & Pucón & 45 & 18.9 & 1990 & 45 & 2.2 \\
\hline & Lago Calafquén & 46 & 17.8 & 2003 & 75 & 1.3 \\
\hline & Llancahue & 47 & 26.4 & 1984 & 65 & 1.5 \\
\hline & Puelo & 48 & 16.1 & 2004 & 18 & 5.6 \\
\hline Cold-semiarid & Punta Arenas & 49 & 13.0 & 1993 & 47 & 2.1 \\
\hline
\end{tabular}

N/A: information not available. 
exceeding this value is only $2.8 \%$, associated with a return period of $36 \mathrm{yr}$. Furthermore, the relationship between the recorded maximum intensity of each data series and its corresponding exceedance probability is illustrated in Figure 2, indicating that the lowest values occurred in the northern regions (hyperarid and arid climates), compared to the other analyzed climate types.

In general, the probability of exceeding a recorded real maximum intensity was less than $10 \%$. However, for the Embalse Lliu-Lliu, Curacautín, and Pueblo Nuevo stations, representing semiarid and humid climates, the recorded maximum intensity was surpassed, which indicates a higher chance of an extreme event exceed the maximum recorded in those areas.

Significant differences between stations and between climatic zones for rainfall intensities were found by the Kruskal Wallis test (Table 4). The largest statistical differences were obtained in the extreme climatic zones, such as hyperarid and cold semiarid climates (Figure 3). However, it is important to point out the fact that stations can reach similar values of maximum rainfall intensity, despite geographic and climatic differences. For example,

Table 4. Statistical comparison of rainfall intensities among different climatic zones, using the Kruskal-Wallis test.

\begin{tabular}{llcrr}
\hline $\begin{array}{l}\text { Type of } \\
\text { comparison }\end{array}$ & \multicolumn{1}{c}{ Sample } & $\begin{array}{c}\text { Sample } \\
\text { size (n) }\end{array}$ & $\begin{array}{c}\text { P-value } \\
\text { hypothesis }\end{array}$ \\
\hline Among climatic zones & Hyperarid & 106 & $<0.05$ & Rejected \\
& Arid-semiarid & 208 & & \\
& Semiarid & 122 & & \\
& Semiarid-Mediterranean & 74 & & \\
& Mediterranean & 187 & & \\
& Subhumid-humid & 154 & & \\
& Humid & 143 & & \\
& Cold semiarid & 26 & & \\
& & & \\
\hline
\end{tabular}

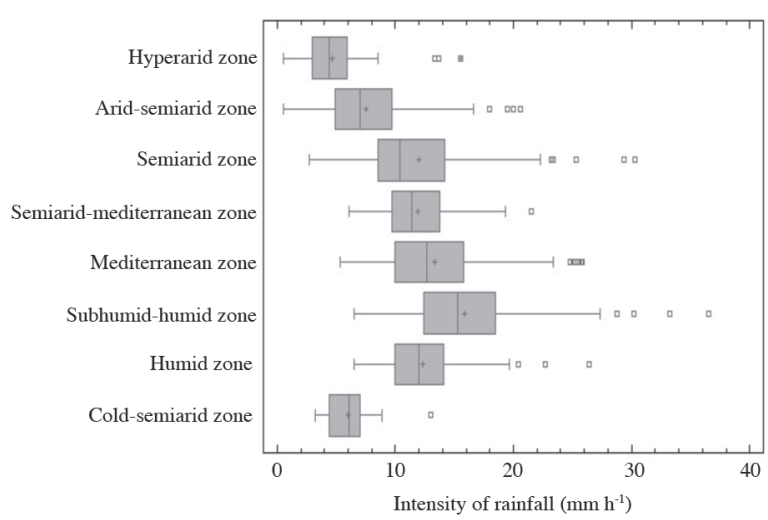

Figure 3. Significant difference on maximum precipitation intensities among climatic zones, after applying the Kruskal-Wallis test (alpha = 0.05).

even though there were significant differences between northern climates (i.e. hyperarid, arid, and semiarid) and central climates (Mediterranean and humid), the largest variability of rainfall intensities happened in arid environments, where higher intensities were common and similar to those recorded in central Chile.

With these results it is possible to discuss the spatial variability of precipitation in Chile, in terms of the proportion between maximum and minimum values for both intensity and total amounts. Maximum values for rainfall intensity (subhumid zone) were as much as 4.5 times the minimum documented values (hyperarid zone), for $\mathrm{T}=5$ and $100 \mathrm{yr}$. However, maximum values for total rainfall (humid zone) surpass by more than 80 times the minimum recorded values (hyperarid zone). This allowed us to verify the differences in amplitude for rainfall

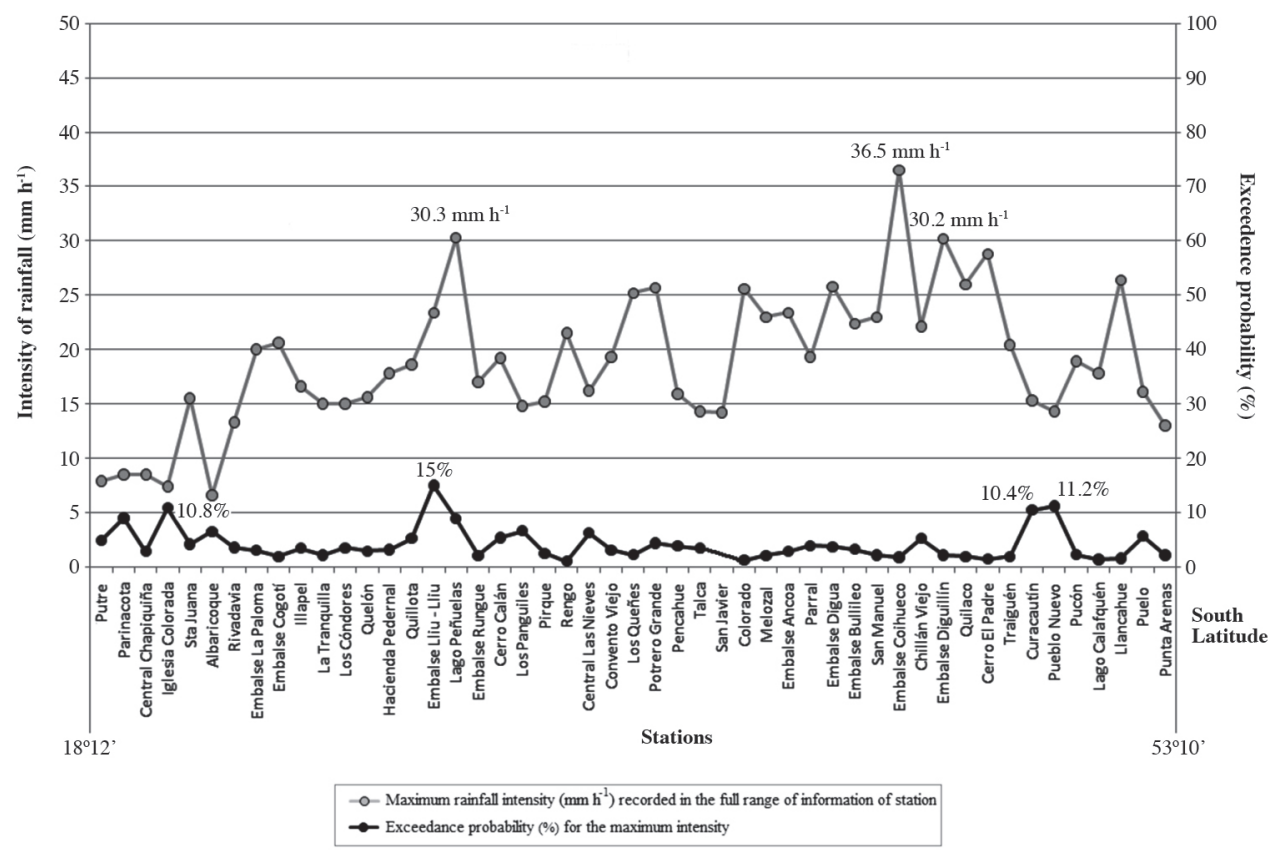

Figure 2. Probability of exceeding the maximum-recorded rainfall intensity at each station. 
intensity and total annual precipitation, showing a much larger contrast in the range of the latter variable.

Although some studies have been done in Chile, they were all focused on the behavior of precipitation. Falvey and Garreaud (2007), Verbist et al. (2010), and Barrett et al. (2011), for example, did not consider variables used in this research. Besides, most of the studies in Chile are based on demonstrating the interannual variability of precipitation in the central portion of the country, which is associated with the El Niño and La Niña phenomena (Rutllant and Fuenzalida, 1991). Furthermore, Garreaud and Aceituno (2001) concluded that the number of rainy days increases during El Niño, particularly moderate (10$\left.20 \mathrm{~mm} \mathrm{~d}^{-1}\right)$ and extreme $\left(50 \mathrm{~mm} \mathrm{~d}^{-1}\right)$ intensities. However, no significant differences were found during La Niña, which means that the number of rainy days during this phenomenon does not necessarily decrease during that particular year.

The analysis of these authors, as well as most of the parametric climate studies developed in Chile, focused on the behavior of total rainfall amounts as they relate to atmospheric phenomena at different spatial scales. However, rainfall intensity is not well understood in Chile. It is more relevant to move forward using IDF curves and expand on the few available studies, mostly because recent statistical analyses show changes in rainfall intensity, in the form of higher rainfall intensity values for shorter lapses; thus, design guidelines on hydraulic structures as well as soil and water conservation works should be modified.

Finally, the relationship between rainfall intensity ( $\mathrm{D}=1 \mathrm{~h}, \mathrm{~T}=5$ and $100 \mathrm{yr}$ ), mean annual precipitation, and latitude (Figure 4) shows no correlation between maximum rainfall intensity and mean annual precipitation in Chile (Table 5), since similar rainfall intensity values were found throughout the country. However, mean annual precipitation gradually increases with latitude, showing a decrease in the extreme south.

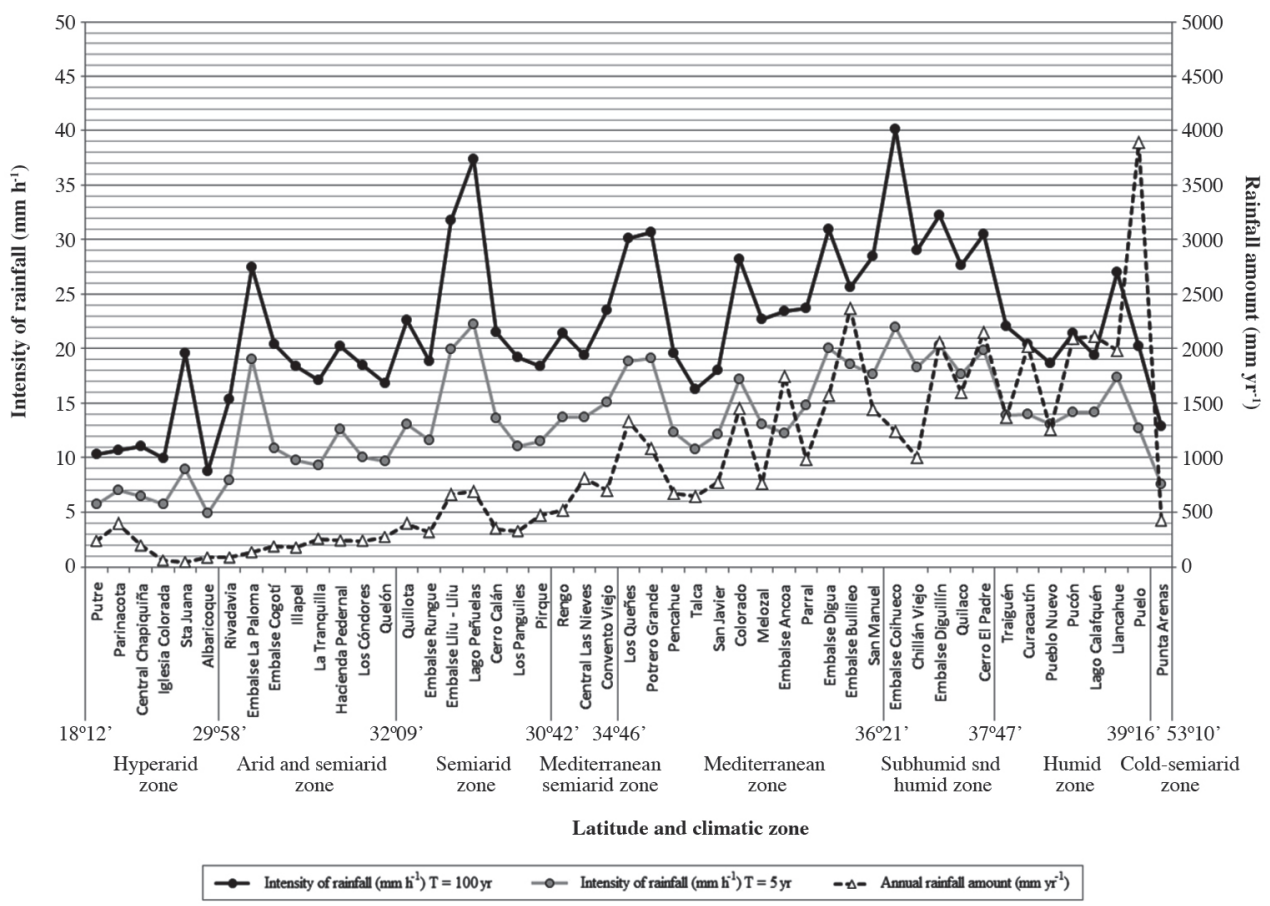

Figure 4. Maximum rainfall intensities $(\mathrm{T}=5$ and $100 \mathrm{yr})$ and mean annual precipitation at different latitudes in Chile.

Table 5. Annual precipitation and maximum one-hour rainfall intensity $(\mathrm{T}=\mathbf{1 0 0} \mathrm{yr}$ ) for different climatic zones in Chile.

\begin{tabular}{|c|c|c|c|c|c|c|}
\hline Climatic zone & Region & Station/Location & $\begin{array}{c}\text { Map } \\
\text { number }\end{array}$ & $\begin{array}{c}\text { South } \\
\text { latitude }\end{array}$ & $\begin{array}{l}\text { Annual } \\
\text { rainfall } \\
\text { amount }\end{array}$ & $\begin{array}{c}\text { Maximum rainfall } \\
\text { intensity } \\
\mathrm{T}=100 \mathrm{yr}\end{array}$ \\
\hline & & & & & $\mathrm{mm}$ & $\mathrm{mm} \mathrm{h}^{-1}$ \\
\hline Hyperarid & Arica y Parinacota & Santa Juana & 5 & $28^{\circ} 40^{\prime}$ & 43.9 & 19.62 \\
\hline Arid-semiarid & Coquimbo & Embalse Cogotí & 9 & $31^{\circ} 00^{\prime}$ & 168.0 & 20.40 \\
\hline \multirow[t]{2}{*}{ Semiarid } & Valparaíso & Hacienda Pedernal & 14 & $32^{\circ} 06^{\prime}$ & 247.5 & 20.22 \\
\hline & Metropolitana & Los Panguiles & 20 & $33^{\circ} 26^{\prime}$ & 361.5 & 19.20 \\
\hline Semiarid-Mediterranean & Libertador General Bernardo O'Higgins & Central Las Nieves & 23 & $34^{\circ} 29^{\prime}$ & 828.9 & 19.37 \\
\hline Mediterranean & Maule & Pencahue & 27 & $35^{\circ} 23^{\prime}$ & 673.0 & 19.56 \\
\hline \multirow[t]{3}{*}{ Humid } & La Araucanía & Curacautín & 43 & $38^{\circ} 26^{\prime}$ & 1750.8 & 20.44 \\
\hline & Los Ríos & Lago Calafquén & 46 & $39^{\circ} 34^{\prime}$ & 2113.7 & 19.39 \\
\hline & Los Lagos & Puelo & 48 & $41^{\circ} 38^{\prime}$ & 3891.0 & 20.21 \\
\hline
\end{tabular}




\section{CONCLUSIONS}

The highest values of rainfall intensity $(D=1 \mathrm{~h}, \mathrm{~T}=5$ and $100 \mathrm{yr}$ ) in Chile are present in subhumid zones $\left(36^{\circ}\right.$ $S$ lat), and total annual precipitation values are higher in humid zones (39 $\mathrm{S}$ lat). Precipitations in Chile have a high amount of spatial variability, a consequence of the wide latitudinal extension of the country. Differences in annual precipitation are noticeable; maximum values that can reach more than 80 times minimum values were observed. However, rainfall intensity does not change with latitude along the country in general, reaching a difference of only 4.5 times between maximum and minimum values.

Finally, we suggest that maximum rainfall intensities distributed in Chile behave similarly throughout the country. However, minimum $\mathrm{D}=1 \mathrm{~h}$ values were documented at the latitudinal extremes of the country (north and south). Similarly, there was no correlation between elevation and rainfall intensity. As indicated previously, Chile has a large variety of climates, in which annual precipitation gradually increases from north to south. However, such pattern has nothing to do with the way rainfall intensities behave, that is, mean annual precipitation does not predict rainfall intensity in Chile.

\section{ACKNOWLEDGEMENTS}

The authors of this study sincerely wish to thank the Dirección General de Aguas of Chile for providing the necessary information to carry out the statistical analyses, and the FONDEF project D08I1054, for providing the necessary funds to obtain the results of this study.

\footnotetext{
Análisis latitudinal de la intensidad de lluvias y precipitación media anual en Chile. El estudio y análisis de las precipitaciones se ha convertido en una herramienta vital para conocer el comportamiento temporal y espacial del recurso hídrico, tanto en términos de disponibilidad, así como de los posibles impactos asociados a los eventos extremos. El objetivo de esta investigación fue evaluar las intensidades máximas (duración $\mathrm{D}=1 \mathrm{~h}$ y períodos de retorno $\mathrm{T}=5$ y 100 años) y los montos anuales de precipitación para diferentes latitudes y zonas climáticas de Chile, analizando la información de miles de bandas pluviográficas y la pluviometría anual de 49 estaciones de medición. Ello, porque aún no es claro que las intensidades de precipitación difieren latitudinalmente en el país, así como lo hacen los montos anuales de las lluvias. Asimismo, no hay evidencia científica de los rangos y montos de ambas variables. Así, se utilizó la función de Gumbel y fórmulas matemáticas para desarrollar las curvas intensidad-duración-frecuencia (IDF) de cada estación. Los valores mínimos y máximos de intensidad de precipitación registrados para $\mathrm{T}=100$
}

años, fueron 8,79 (zona hiperárida) y $40,17 \mathrm{~mm} \mathrm{~h}^{-1}$ (zona subhúmeda-húmeda). Respecto al monto anual de precipitaciones, los valores mínimos y máximos fueron 43,9 (zona hiperárida) y $3891,0 \mathrm{~mm}$ año ${ }^{-1}$ (zona húmeda) respectivamente. Adicionalmente, la intensidad máxima real registrada en cada estación fue analizada para determinar su probabilidad de excedencia. Asimismo, se realizaron comparaciones múltiples para detectar diferencias significativas entre las estaciones de medición y las diferentes zonas climáticas, mediante el test no paramétrico Kruskal Wallis (alfa $=0,05)$. Las diferencias entre los valores máximos y mínimos registrados en la totalidad de las estaciones analizadas pueden superar las 80 veces, para el caso de los montos anuales de las lluvias, y pueden llegar hasta 4,5 veces para el caso de las intensidades de precipitación ( $T=100$ años). Sin embargo, se encontraron valores máximos similares de intensidad de precipitación en diferentes latitudes y altitudes del territorio nacional. Por tanto, se concluye que un mayor monto anual de lluvia no necesariamente involucra una mayor intensidad de precipitación.

Palabras clave: Precipitaciones, curvas intensidadduración-frecuencia, curvas IDF, intensidad de precipitaciones.

\section{LITERATURE CITED}

Barrett, B.S., D.B. Krieger, and C.P. Barlow. 2011. Multi-day circulation and precipitation climatology during winter rain events of differing intensities in central Chile. Journal of Hydrometeorology 12:1071-1085.

Bernard, M. 1932. Formulas for rainfall intensities of long durations. Transactions of ASCE 96:592-624

Bougadis, J., and K. Adamowski. 2006. Scaling model of a rainfall intensity-duration-frequency relationship. Hydrological Processes 20:3747-3757.

Chow, V., D. Maidment, and L. Mays. 1994. Applied hydrology (en español). 572 p. McGraw-Hill Interamericana, Bogotá, Colombia.

Dairaku, K. 2004. Rainfall amount, intensity, duration, and frequency relationships in the Mae Chaem Watershed in Southeast Asia. Journal of Hydrometeorology 5:458-470.

Dickinson, T. 1977. Rainfall intensity-frequency relationships from monthly extremes. Journal of Hydrology 35:137-145.

Dougherty, E.R., S. Kim, and Y. Chen. 2000. Coefficient of determination in nonlinear signal processing. Signal Processing 80(10):2219-2235.

Errázuriz, A.M., P. Cereceda, J. González, M. González, and R. Rioseco. 1998. Manual de geografía de Chile. $3^{\text {rd }}$ ed. 435 p. Editorial Andrés Bello, Santiago, Chile.

Falvey, M., and R. Garreaud. 2007. Wintertime precipitation episodes in Central Chile: Associated meteorological conditions and orographic influences. Journal of Hydrometeorology 8:171193.

Garreaud, R., and P. Aceituno. 2001. Interannual rainfall variability over the South American Altiplano. Journal of Climate 14:27792789.

Grimaldi, S., S.C. Kao, A. Castellarin, S.M. Papalexiou, A. Viglione, F. Laio, et al. 2011. Statistical hydrology. p. 479-517. Treatise on Water Science, Elsevier, Oxford, UK.

Gumbel, E. 1958. Statistics of extremes. 400 p. Dover Publications, Mineola, New York, USA.

Haan, C. 2002. Statistical methods in hydrology. 496 p. Iowa State Press, Ames, Iowa, USA. 
Hallack-Alegria, H., and D. Watkins Jr. 2007. Annual and warm season drought intensity-duration-frequency analysis for Sonora, Mexico. Journal of Climate 20:1897-1909.

IGM. 2008. Atlas geográfico de Chile. 280 p. Instituto Geográfico Militar (IGM), Santiago, Chile.

INE. 2007. División político-administrativa y censal 2007. Instituto Nacional de Estadísticas (INE), Santiago, Chile. Available at http://www.ine.cl/ (accessed June 2010).

Kruskal, W., and W. Wallis. 1952. Use of ranks in one-criterion variance analysis. Journal of the American Statistical Association 47(260):583-621.

Langousis, A., and D. Veneziano. 2007. Intensity-duration-frequency curves from scaling representations of rainfall. Water Resources Research 43(2). 12 p.

Linsley, R., M. Kohler, and J. Paulus. 1977. Hidrología para Ingenieros. $2^{\text {a }}$ ed. 386 p. McGraw-Hill Latinoamericana, D.F. México.

Maidment, D. 1996. Handbook of hydrology. 784 p. American Society of Civil Engineers, New York, USA.

Martínez-Mena, M., R. Abadía, V. Castillo, y J. Albaladejo. 2001. Diseño experimental mediante lluvia simulada para el estudio de los cambios en la erosión del suelo durante la tormenta. Cuaternario y Geomorfología 15(1-2):31-43.

Massey, F.J., Jr. 1951. The Kolmogorov-Smirnov test for goodness of fit. Journal of the American Statistical Association 46(253):6878.

Minh Nhat, L., Y. Tachikawa, T. Sayama, and K. Takara. 2008. Estimation of sub-hourly and hourly IDF curves using scaling properties of rainfall at gauged site in Asian Pacific Region. Annuals of Disaster Prevention Research Institute, Kyoto University. $\mathrm{N}^{\circ}$ 51B

Minh Nhat, L., Y. Tachikawa, and K. Takara. 2006. Establishment of Intensity-Duration-Frequency curves for precipitation in the monsoon area of Vietnam. Annuals of Disaster Prevention Research Institute, Kyoto University. $\mathrm{N}^{\circ}$ 49B.

Mintegui, J., and J. Robredo. 1993. Métodos para la estimación de los efectos torrenciales en una cuenca hidrográfica. 88 p. Fundación Conde del Valle de Salazar, Escuela Técnica Superior de Ingenieros de Montes, Universidad Politécnica de Madrid, Madrid, España.

Monsalve, G. 1999. Hidrología en la ingeniería. 2a ed. 382 p. Editorial Alfa Omega S.A., Santa Fé de Bogotá, Colombia.

Ott, R.F. 1971. Stream flow frequency using stochastically generated rainfall. Technical Report 151. 111 p. Department of Civil Engineering, Stanford University, Palo Alto, California, USA.

Paulhus, J.L., and J.F. Miller. 1957. Flood frequencies derived from rainfall data. Journal of Hydraulical Division. American Society of Civil Engineering Paper 1451, Vol. 83. 18 p.

Pereyra-Díaz, D., J.A. Pérez-Sesma, and L. Gómez-Romero. 2004. Ecuaciones que estiman las curvas intensidad-duración-período de retorno de la lluvia. Geos 24:46-56.

Pizarro, R. 1986. Elementos técnicos de hidrología. 78 p. Corporación Nacional Forestal (CONAF), La Serena, Chile.

Pizarro, R., A. Abarza, y J. Flores. 2001. Análisis Comparativo de las Curvas Intensidad - Duración - Frecuencia (IDF) en 6 Estaciones Pluviográficas (VII Región del Maule, Chile). Universidad de Talca, Facultad de Ciencias Forestales, Talca, Chile. Revista Virtual de UNESCO. 48 p. Available at http://www.unesco.org. uy/phi/biblioteca/bitstream/123456789/500/1/curvas+idf+maule. pdf (accessed 5 September 2011).

Pizarro, R., F. Cornejo, C. González, K. Macaya, y C. Morales. 2008. Análisis del comportamiento y agresividad de las precipitaciones en la zona central de Chile. Ingeniería Hidráulica en México 23(2):91-109.
Pizarro, R., C. Sangüesa, J. Flores, and E. Martínez. 2005. Elementos de Ingeniería Hidrológica para el mejoramiento de la productividad silvícola. Proyecto marco: 00C7FT-08 "Determinación de estándares de ingeniería en obras de conservación y aprovechamiento de aguas y suelos para la mantención e incremento de la productividad silvícola". Universidad de Talca, Talca, Chile. 179 p. Available at http://eias.utalca.cl/Docs/pdf/ Publicaciones/libros/elementos_de_ingenieria_hidrologica_para_ el_mejoramiento_de_la_productividad_silvicola.pdf (accessed 29 August 2011).

Ponce, V. 1989. Engineering hydrology: Principles and practices. 640 p. Prentice Hall, Englewood Cliffs, New Jersey, USA.

Rutllant, J., and H. Fuenzalida. 1991. Synoptic aspects of the central Chile rainfall variability associated whit the Southern Oscillation. International Journal of Climatology 11:63-76.

Sangüesa, C., J. Arumí, R. Pizarro, and O. Link. 2010. A rainfall simulator for the in situ study of superficial runoff and soil erosion. Chilean Journal of Agricultural Research 70:178-182.

Témez, J. 1978. Cálculo hidrometeorológico de caudales máximos en pequeñas cuencas naturales. 111 p. Dirección General de Carreteras, Madrid, España.

UNESCO. 2006. Guía metodológica para la elaboración del mapa de zonas áridas, semi-áridas y sub-húmedas secas de América Latina y el Caribe. Centro del Agua para Zonas Áridas y Semiáridas de América Latina y el Caribe (CAZALAC). Documento Técnico PHI-LAC $\mathrm{N}^{\circ}$ 3. 66 p. Programa Hidrológico Internacional de la UNESCO para América Latina y el Caribe (PHI-LAC), Organización de las Naciones Unidas para la Educación, la Ciencia y la Cultura (UNESCO), Oficina Regional de Ciencia para América Latina y el Caribe, Montevideo, Uruguay.

UNESCO. 2007. Curvas Intensidad-Duración-Frecuencia para la zona centro sur de Chile. Roberto Pizarro Tapia, Dayanna Aravena Garrido, Karina Macaya Pérez, Alejandro Abarza Martínez, Mariela Cornejo Espinoza, Mauricio Labra Lorca, Marcelo Pavez Vidal, Leonardo Román Arellano. Editorial Universidad de Talca, Talca, Chile. Documento Técnico PHI-LAC No 7. 135 p. Programa Hidrológico Internacional de la UNESCO para América Latina y el Caribe (PHI-LAC), Organización de las Naciones Unidas para la Educación, la Ciencia y la Cultura (UNESCO), Oficina Regional de Ciencia para América Latina y el Caribe, Montevideo, Uruguay.

UNESCO. 2010. Atlas de zonas áridas de América Latina y el Caribe. Dentro del marco del proyecto "Elaboración del Mapa de Zonas Áridas, Semi-Áridas y Sub-húmedas Secas de América Latina y el Caribe". Documento Técnico PHI-LAC N 25. 55 p. Programa Hidrológico Internacional de la UNESCO para América Latina y el Caribe (PHI-LAC), Organización de las Naciones Unidas para la Educación, la Ciencia y la Cultura (UNESCO) y el Centro del Agua para Zonas Áridas de América Latina y el Caribe (CAZALAC). Available at http://www.cazalac.org/documentos/ Atlas_de_Zonas_Aridas_de_ALC_Espanol.pdf (accessed 10 September 2011).

Veneziano, D., and P. Furcolo. 2002. Multifractality of rainfall and scaling of intensity-duration-frequency curves. Water Resources Research 38(12), 1306. doi:10.1029/2001WR000372.

Verbist, K., A.W. Robertson, W.M. Cornelis, and D. Gabriels. 2010. Seasonal predictability of daily rainfall characteristics in Central Northern Chile for dry-land management. Journal of Applied Meteorology and Climatology 49:1938-1955.

Watkins, D. Jr., G. Link, and D. Johnson. 2005. Mapping regional precipitation intensity duration frequency estimates. Journal of the American Water Resources Association 41:157-170.

Willems, P. 2000. Compound intensity-duration-frequencyrelationships of extreme precipitation for two season and two storm types. Journal of Hydrology 233:189-205. 